\title{
A PERSPECTIVA FILOSÓFICA DO CONCEITO DE ESSÊNCIA (QUOD QUID EST) EM JOÃO DUNS SCOTUS: O PROBLEMA DA QUOD QUID EST SINGULAR.
}

\section{THE PHILOSOPHICAL PERSPECTIVE OF THE CONCEPT OF ESSENCE (QUOD QUID EST) IN JOHN DUNS SCOTUS: THE MATTER OF THE SINGULAR QUOD QUID EST.}

\author{
Maurício Alves Carrara ${ }^{1}$
}

Universidade Federal de São João Del Rei.

\begin{abstract}
Resumo: O conceito de essência, durante a Idade Média, não foi concebido de forma una nos mil anos da era medieval. A partir do século XIII, com a entrada da obra Metafísica de Aristóteles o conceito de essência começou a tomar contornos mais realistas. João Duns Scotus (c.12261308) desenvolve este conceito com bases em Aristóteles e Avicena, mas se diferencia dos dois. Scot passa a entender a essência como algo próprio dos últimos indivíduos. Assim, ele faz de outro modo em relação aos seus anteriores na Idade Média. Este artigo tem por propósito apresentar esta originalidade do Doctor Subtilis em relação ao seu conceito de essência (quod quid est).
\end{abstract}

Palavras-chave: Singularidade, essência (quod quid est), indivíduo.
Abstract: The concept of essence, during the Middle Age, did not planned just one way during the thousand years on the medieval age. From the 13th century, with the entrance of the work Metaphysics of the Aristotle, the concept of essence began taking realists contours. John Duns Scot (c.1226-1308) develops this concept with bases on Aristotle and Avicenna but he made a new vision. Scot understands the essence how something owned of the last individuals. Thus, he does a different concept of essence compared to his previous on the Middle Age. This article has for purpose to show the original way of Duns Scot about the concept of essence (quod quid est).

Keywords: Singularity, essence (quod quid est), being individual.

\footnotetext{
${ }^{1}$ Mestrando em História, Universidade Federal de São João Del Rei. E-mail: carraramac@gmail.com.
} 


\section{Introdução.}

Por volta de 1300, Duns Scotus já havia concluído suas obrigações como estudante da universidade de Oxford. Porém as grandes questões sobre a sua filosofia estavam ainda em gestação. Em Paris o seu trabalho teológico, então, ainda se configurava ${ }^{2}$.

O conceito de essência de Duns Scotus deve ser entendido em dois aspectos: A) o primeiro é a sua localização em um contexto maior que leva em conta os seus posicionamentos diante das questões filosóficas de seu tempo. Temos, portanto, que considerar aspectos como: a instituição universitária e a tentativa de parte da Igreja de estabelecer quais eram as proposições filosóficas consideradas contrárias à fé; B) o segundo tópico diz respeito aos temas que Duns Scotus se dedicou para que possamos, estudando-os, extrair o conceito chave da pesquisa: a essência e como esta se processa ${ }^{3}$. Assim, em virtude destes dois aspectos, desenvolve-se a originalidade de Scotus diante de seus antecessores.

A novidade do corpus metafísico de Aristóteles, no século XIII, trouxe novos problemas para o conceito de essência principalmente em relação à individuação ${ }^{4} \mathrm{O}$ debate sobre os individuais paulatinamente se "ontologiza". As concepções de individualidade e de "individuação" passam a ser colocadas como coisas reais na medida em que os critérios de quantidade do objeto, matéria constituinte, relação agente e atualidade (pro statu isto) e positividade do objeto ganham mais vivacidade em detrimento de uma filosofia de base essencialmente lógica e ante rem de cunho platônico ${ }^{5}$.

${ }^{2}$ WILLIANS, Thomas. Introduction. The life and works of John Duns the Scot. In: WILLIANS, Thomas (Ed.). The Cambridge Companion to Duns Scotus. Cambridge: University Cambridge Press, 2003. p. 4 ;

DE BONI, Luis Alberto. Sobre a vida e a obra de Duns Scotus. VERITAS, Porto Alegre, v. 53, n. 3, jul./set. 2008, p. 8.

${ }^{3}$ Aqui tratamos a essência em Duns Scotus não como um dado acabado, mas como uma constructio. A essência escotista é tida como o dado mais original do Doutor Sutil, porém ela é desenvolvida diante de uma base maior e filosoficamente "tortuosa". Apesar de Scotus se dedicar, em algumas partes, a ela integralmente, a essência deve ser entendida diante de questões maiores como os temas da individualidade e da individuação. Creio que criar uma síntese puramente "enciclopédica" sobre o conceito de essência pode, em minha concepção, desvirtuar algumas características fundamentais e menos óbvias contidas na filosofia de Duns Scotus. Encontramos com o decorrer deste capítulo, ao ler as obras em latim do Doctor Subtilis, temas considerados como inferiores pela historiografia da filosofia que são basilares para o entendimento do conceito de essência escotista. Por outro lado, temas "super-valorizados"são, na verdade, de importância igual aos desvalorizados, não cabendo, assim, uma grande importância dada por alguns pesquisadores, mas que devem ser estudados com muito cuidado.

${ }^{4}$ A individuação é uma categoria filosófica que implica em como que as coisas reais tornam-se indivíduos. Porém a idéia de indivíduo e individualidade na filosofia da Idade Média está longe de ser aquela que entendemos atualmente: o indivíduo como alguém constituído de particularidades diante de uma meio social, isto é, uma parte diante do todo no corpo social ou como as democracias atuais entendem. Aqui a individualidade e o indivíduo são categorias filosóficas.

${ }^{5}$ NOONE, Timothy. Universals and Individuation. In: WILLIANS, Thomas (Ed.). The Cambridge Companion to Duns Scotus. Cambridge: University Cambridge Press, 2003. p. 112.

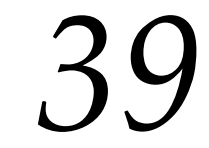


O estudo da essência em Duns Scotus prova que não existem problemas perenes em filosofia. A contingência social e histórica, expressa no meio intelectual, exemplifica que os meios em que a filosofia circula podem "moldar" o pensamento filosófico.

Todo artifício lógico expresso anteriormente nas concepções de individualidade quebra-se em prol de problemas mais "reais", isto é, filosoficamente falando. Antonie Vos demonstra estas mudanças filosóficas na época de Scotus:

Durante estes notáveis anos, a metade dos anos de 1290, tudo mudou. (...) A sua ontologia (de Duns Scotus) dos individuais é um bom exemplo de como a filosofia muda. Isto, porque, suas implicações teológicas, o problema da individuação, em uma porção do final do século XIII, se torna uma das mais controversas e acaloradas discussões nos círculos universitários, especialmente Paris e Oxford. ${ }^{6}$

A concepção sobre o individual de Scotus não é uma simples apreensão filosófica estática e reproduzida sem um questionamento aprofundado. O Doutor Sutil inverte a óptica dos indivíduos dando-os mais "qualidades" do que "quantidades". Isto significa que os indivíduos não são meros números, mas essencialmente caracterizáveis. Assim, a individuação de Scotus se dá no nível da essência e, por sua vez, unívoca (idêntica a si mesma) ${ }^{7}$.

Com isso, a individualidade, a individuação e a essência caminham pari-passu. Além disto, Scotus delega o estudo destas questões à metafísica, pois entre a metafísica e outra ciência, concernente à essência, a primeira é a responsável pela qüididade das coisas. A essência para Scotus é um problema real e a metafísica trata tanto dos indivíduos reais quanto dos comuns reais. Naturalmente, segundo Scotus, a metafísica não é lógica (metaphysica non est logica) ${ }^{8}$, mas responsável em entender aquilo que é imbuído de realitas (realidade).

A individuação ${ }^{9}$ é o caminho para que a teoria da "essência" de Duns Scotus seja aplicada. A especulação sobre a materialidade das coisas e como que algo pode ser chamado de um verdadeiro indivíduo ou o "um por si" (unum per se) é a razão que Scotus encontra para que sua teoria da essência seja desenvolvida. Assim, para o ser real, isto é, o último possível, o ser e o uno são inseparáveis ${ }^{10}$.

\footnotetext{
${ }^{6}$ VOS, Antonie, The Philosophy of John Duns Scot. Edinburgh: Edinburgh University Press, 2006, p. 397.

7 JOLIVET, Jean. La Filosofía Medieval em Occidente. México: Siglo Veintiuno Editores, 1985 p.282.

${ }^{8}$ Idem, p. 283

${ }^{9}$ Duns Scotus dá uma atenção especial ao "Princípio da Individuação" em suas obras. Elas atuaram como título principal De princípio individuationis conforme a referência: Opera Omnia. Ordinatio: liber secundus: a distinctione prima ad tertiam. Tomo VII. Romae: Civitas Vaticana, 1973. p. 391-516 e Distinctio Tertia, Pars Prima: De principio individuationis. In: Opera Omnia Lectura in librum secundun setentiarum. A distincione prima ad sextam. Tomo XVIII. Romae: Civitas Vaticana, 1983. p. 228-301. E em outros pontos esparços na Quaestiones Super Libros Metaphysicorum Aristotelis.

${ }^{10}$ GILSON, Étienne. Jean Duns Scot Introduction a sés positions fondamentales. Paris: J. Vrin, 1952. p. 452.
}

\section{0}


As ressalvas filosóficas que se estendem até o fim do século XIII, causadas pelas condenações de 1277, demonstram o clima de mal-estar provocado por este choque intelectual. Diante deste fato, Scotus cria seu modelo filosófico não necessariamente entre dois pólos. Por outro lado, a via que ele traça discorda de algumas posições aristotélicas e também da filosofia de fundo platônico ${ }^{11}$. Em suma, há uma reapropriação e reinterpretação dos conceitos aristotélicos por parte de Scotus, apresentando novas vias às idéias de matéria, forma, essência, acidente e substância.

Posto isto, podemos demonstrar os princípios filosóficos de Duns Scotus através do entendimento de como podemos interpretar a formação do indivíduo, bem como a sua essência.

\section{A construção filosófica do conceito de essência (quod quid est) em Duns Scotus.}

Em um primeiro momento, eis a primeira questão ${ }^{12}$ levantada por Scotus sobre a essência ${ }^{13}$ : qual é a ciência que tem por propriedade estudar e aprofundar na própria qüididade ${ }^{14}$ dos particulares? A essência como objeto de análise filosófica só a metafísica pode estudá-la: "Se à Metafísica, enquanto tal é pertinente por si conhecer toda qüididade em particular" 15. A separação das ciências e a importância que a metafísica tem para que, ontologicamente, possamos interpretar a essência é fundamental, pois Duns Scotus afirma, apoiado em Aristóteles, que: "nenhuma outra ciência faz uma consideração a partir da própria "quod quid est" ${ }^{16}$. Mas não só por isso:" que ao metafísico é cabível conhecer qüididade segundo o que 'qüididade' e segundo "esta" 17.

${ }^{11}$ KENNY, Anthony. Medieval Philosophy. A New History of Western Philosophy. New York: Oxford University Press, 2007, vol. 2, p.85.

${ }^{12}$ Quaestiones Super Libros Metaphysicorum Aristotelis, Liber I, Quaestio 9, 1-52. Para facilitar a citação dos textos de Duns Scotus, usarei assim: Quaes. Super (relativo ao livro), L. (livro), Q. (Questão), 3 (parágrafo).

${ }_{13}$ Cabe ressaltar que neste livro, Duns Scotus, está interessado em apresentar os vários meios pelos quais o metafísico deve considerar a "quod quid est" como próprio da ciência metafísica. Desta maneira, é pertinente colocar cada ponto que Scotus esclarece que leve em conta o universal, particular, acidente, quantidade e qualidade. A tortuosidade do texto escotista apresenta um duplo propósito: investigar o que é a qüididade e ao mesmo tempo apresentar a qüididade como algo próprio do estudo do metafísico. Naturalmente não poderemos dar um conceito objetivo sobre o que é a essência, pois corremos o risco de empobrecer a investigação de Scotus.

${ }^{14}$ Muitos são os termos encontrados em Scotus para entendermos a essência. Em português comumente encontramos a tradução dos termos latinos quod quid est, quod quid erat esse, quidditas e quididate como essência pura e simples. Ressalto aqui que usarei todos estes termos para me referir à essência. Em respeito ao original em latim, as palavras variarão no meu texto, mas todas elas se referem à essência.

15 Utrum ad metaphysicum, in quantum talis, per se pertinet cognocere omnes quiditates in particulari. Quaes. Super, L. I, Q.9, 1.

${ }^{16}$ Nulla alia scientia facit considerationem de ipso 'quod quid est'. Quaes. Super, L. I, Q.9, 1.

${ }^{17}$ Quod ad metaphysicum pertinet cognocere quamlibet quiditatem secundum quod 'quiditas' et secundum quod 'haec'. Quaes. Super, L. I, Q.9, 6.

\section{1}


O direcionamento que o metafísico dá aos seres tem condições de se chegar aos particulares e, por seqüência, à sua essência. Por esta razão, a ciência metafísica é aquela que na realidade condiciona o estudo das qüididades.

$\mathrm{Na}$ investigação sobre a qüididade pode-se encontrar duas formas que se contrastam: a dos particulares e a dos universais. Em contraposição aos particulares, é impossível para o universal, enquanto comum a muitos, ter algum tipo de propriedade que possa adquirir a característica qüiditativa. A princípio, o universal é incompleto e imperfeito e, ao mesmo tempo, confuso e indistinto ${ }^{18}$.

Entre o universal e o particular existe uma ordem que seria de "superioridade" e "inferioridade". Porém Duns Scotus não vê os critérios de inferioridade e superioridade como uma hierarquia nas coisas, mas como que algo (aliquid) pode ser mais ou menos geral em sua apreensão enquanto ser. Isto é, das ordens (superiores e inferiores) a que está mais para o propósito da investigação escotista é o particular. Assim, entre os superiores e os inferiores pode-se visualizar a condição que o "próprio" ou "modo de ser" (Scotus chama de habitus) é em sua "ordem" e "potência". Para ficar mais claro: "Logo, pela mesma razão, o hábito superior conhece tudo o que é conhecido do hábito inferior. Mas os hábitos inferiores conhecem em particular" ${ }^{19}$. A ordem (inferiores e superiores) é o princípio do conhecimento. Porém a potência é aquilo que tem, por modo, algum indicativo se existe a possibilidade da categoria estar ou não para o que se analisa (e.g. se universal, universal; se particular, particular). Como exemplo, o universal não é "potencialmente" capaz, pelos seus modos, de possuir uma qüididade em particular, pois ele é aquilo que se dá em muitos. Logo, ele pode ser encontrado nos particulares, mas jamais fará um particular como "isto" (hoc). Por uma questão de ordem, o universal estará ligado à comunidade e ao anterior e não ao posterior ou último.

Como ao metafísico é cabível a investigação da essência (quiditas), é necessário que este defronte, por um mérito analítico, a parte essencial dos particulares com a questão acidental ${ }^{20}$. Em primeiro lugar, o confronto entre essência e o acidente se dá pela ordem do que pode ser a partir de si e daquilo que pode ser adicionado ao ser. Entre a possibilidade de adição e a essência, a qüididade é aqui o que inclui em um ser de forma qualitativa. Diferente do acidente, a característica essencial será fundamentada em suas próprias razões (a partir de si). Estas razões da própria coisa (ipsius rei) é o que Scotus chama de "ratione quiditativa" (razão qüiditativa). Por outro lado, o acidente é uma característica dos entes acidentais "extrínsecos", ou seja, não é próprio "in se" ou "per se". Com isso, por esta razão o acidente não é substância:

\footnotetext{
${ }^{18}$ Quaes. Super, L. I, Q.9, 2.

${ }^{19}$ Ergo similiter habitus superior cognoscet omnia quae cognoscuntur in habitibus inferioribus. Sed inferiores habitus cognoscunt in particulari (...). Quaes. Super, L. I, Q.9, 3.

${ }^{20}$ Duns Scotus separa claramente o que é acidental e o essencial. Como é próprio de seus argumentos e, também, uma característica das disputas da escolástica, ele fundamenta as razões pelas quais o acidente não pode ser visto como característica acidental. Esta investigação se dá nesta referência: Quaes. Super, L. VII, Q.1, 1-39. A premissa da questão é "Se a inerência é a partir da essência dos acidentes".
} 
Não é, portanto, a causalidade em substância do acidente com relação a todos os acidentes, nem é a entidade maior entidade perfeita, nem da ordem essencial nas entidades (...). Não pela substância e nem por relação a si própria ${ }^{21}$.

Na relação com o próprio, é a substância e a matéria que colocarão os acidentes e a essência como antagônicos. E na conclusão de Duns Scotus fica assim definido: "se a substância é matéria, não é 'ex qua', mas 'in qua'" 22.

No posicionamento de Duns Scotus temos que considerar um "isto" (hoc) em primeiro plano. Mas aquilo o que é "isto" pode possuir alguma característica fundamental em si que possa ser "per accidens" ou "per quiditatem". Agora será que a metafísica considera a qüididade e o acidente como iguais em suas funções nos seres? A resposta de Scotus é que não. Para que possamos saber como que a essência de algo se processa, a "quantidade" e a "qualidade" são os meios. Se apreendermos a idéia de "quantidade" as ligaremos aos acidentes. Segundo a posição de Scotus, "esta" (haec), enquanto acidente, será nada mais do que acidental, ou seja, nenhuma característica especial: "esta qüididade é a primeira aos acidentes e os acidentes, por si, em relação dos seus primeiros acidentes por meio dos acidentes" ${ }^{23}$. Os acidentes são por si mesmos propriedades da quantidade (quantum). Se a qüididade for uma característica acidental ela não pode pertencer à metafísica, mas à outra ciência ${ }^{24}$.

A característica qüiditativa de algo tem por sua razão ser qualitativa. A perspectiva de qualidade não permite que a "quod quid est" seja enumerada como anterior e posterior (e.g cognitione, definitione et tempore), pois seria relacionada ao movimento ou em relação ao conjunto de características numerais no quantum ${ }^{25}$. A qüididade, para Scotus, deve ser separada de qualquer aspecto quantitativo. A separação da quantidade da parte qüiditativa tende ser apenas da substância da qüididade (tantum quiditas substantiae) ${ }^{26}$ e nunca algo quantitativo.

\footnotetext{
${ }^{21} \mathrm{Nec}$ igitur causalitas in substantia respectu totius accidentis, nec maior perfectio entitatis, nec ordo essentialis in entitate (...). Non per substantia, nec per respectum ad ipsam. Quaes. Super, L. VII, Q.1, 30.

${ }^{22} \mathrm{Si}$ substantia est materia, no ex qua sed in qua. Quaes. Super, L. VII, Q.1, 39.

Cabe aqui uma ressalva. Preferi não traduzir estes dois termos: "in qua" e "ex qua", mas, respectivamente, eles imprimem literalmente a idéia de "dentro do qual" e "fora do qual". A inexatidão de um correspondente em português pode empobrecer o original latino. De forma sintética pode-se ficar entendido que a substância é própria dos seres sendo ela primária ou secundária. Neste sentido, Scotus segue a concepção de Aristóteles na teoria das substâncias que o Estagirita desenvolveu ao longo da Metafísica. Assim, a substância para Scotus parte do próprio ser e não de fora o que separa a característica acidental (ex qua) da substancial (in qua).

${ }^{23}$ Haec quiditas prior est accidentibus, et accidentia per se respectu eius priora accidentibus per accidens. Quaes. Super, L. 1, Q.9, 15.

${ }^{24}$ Quaes. Super, L. I, Q.9, 17.

${ }^{25}$ haec quiditas est prior 'cognitione, definitione et tempore' motu et quantitate; illa ergo potest considerari absque illis. Sed non in scientia naturali, quia considerat mobilia; Nec mathematica, quia considerat quanta. Quaes. Super, L. I, Q.9, 7.
}

${ }^{26}$ Quaes. Super, L. I, Q.9, 35.

\section{3}


Por sua vez, o "isto" essencialmente é parte de sua própria razão (per se) e de mais ninguém. Não é acidental ou quantitativo, mas analiticamente qualitativo, pois a razão é ele próprio. Se algo se faz por sua própria razão ele não pode ser adicionado de mais nada exterior. Caso contrário, o "haec per se" não seria sua própria razão e não seria um particular essencialmente coerente com a sua própria existência. À qüididade nada pode ser adicionado, pois, caso contrário, ela não seria algo "per se", mas "per aliquam" (por meio de outro). Se isto fosse possível, a metafísica, que por sua vez se dedica à qüididade, seria subalterna, pois a qüididade não se tornaria particular com uma razão intrínseca, mas adicional.

Em dois momentos podemos confirmar esta proposição de Duns Scotus:

$1^{\circ}$ ) "Digo que é necessário para o "próprio" conceder a subalternação. Prova: a condição de uma "subalternidade" da ciência é que o sujeito (objeto) seu esteja sob o sujeito "subalternante $27 " 28$, esta primeira razão se liga ao modo e como que se processa a subordinação. Como e quem será quem nas ordens da subordinação.

$\left.2^{\circ}\right)$ " que a subalternada apenas adiciona sobre os outros o sujeito acidental para a diferença (...) que as mais subalternas adicionam mais a diferença acidental do que a essencial"29. É necessária uma ordem como no exemplo: temos dois objetos, um é A e sua essência e outro um acidente qualquer +. Contudo queremos um "quid", ou seja, um o que é. Porém ele se tornou um "quid" da seguinte maneira: A essencial +. Ele agora é um, mas não de si, pois foi adicionado algo. Com isso, o A essencial é subalterno em relação ao +, pois o + é o que faz com que ele se tornasse "quid" (accidentalem differentiam quam essentialem).

O ponto tratado acima revela a desconsideração de Scotus das características acidentais como princípio qüiditativo. Antonie Vos, afirma que Scotus constrói a sua teoria da individualidade em bases não-acidentais. $\mathrm{O}$ realismo escotista sobre os individuais, antes de tudo, é um realismo qualitativo que traz fortemente uma noção de identidade contra a característica acidental como definidora do ser individual ${ }^{30}$. Desta forma, o Doutor Sutil quer apresentar que a essência ou qüididade merece um lugar especial, pois ela é algo necessariamente por si. Por isso, é necessário que o particular seja bem definido para que a característica essencial deste particular seja

\footnotetext{
${ }^{27}$ A palavra subalternante não existe no português. Por outro lado não me senti intimidado em traduzir o original latino de subalternantis pela referida palavra. Contudo, com o perdão por usar este neologismo, digo que a intenção de Duns Scotus era colocar a palavra subalternantis como "aquele que está subordinado a alguma coisa".

28 Dico quod necesse est ipsos concedere subalternationem. Probatio: condicio una subalternatae scentiae est quod subiectum suum sit sub subiecto subalternantis. Quaes. Super, L. I, Q.9, 40.

${ }^{29}$ Quod subalternata tantum addit supra alterius subiectum accidentalem differentiam (...) quod magis subaltenatae addunt accidentalem differentiam quam essentialem. Quaes. Super, L. I, Q.9, 40.

${ }^{30}$ VOS, 2006: 399.
}

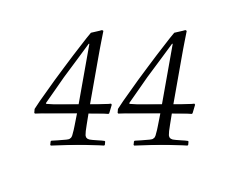


demonstrada sem a adição de algo. O particular é o ponto de partida para que verdadeiramente a essência seja conhecida. A relação qüiditativa que se estabelece com o particular deve possuir alguma correspondência com a realidade e, desta forma, a materialidade.

Com base nesta construção, Duns Scotus inicia a questão: "se nas coisas materiais a matéria é parte da coisa qüiditativa" ${ }^{31}$. Entre a coisa material e a parte qüiditativa, Scotus reafirma a sua ligação com os particulares. Pois se existe um particular, há a necessidade de ter um princípio que o faz próprio em si mesmo e que possamos o conhecer: "a 'quod quid est' é o princípio conhecível (reconhecível) daquilo que $e^{\prime \prime} 32$. Scotus quer considerar que a qüididade está na coisa e, ao mesmo tempo, levar em conta que a coisa material é parte constitutiva de qualquer ser na sua condição "pro statu isto", ou seja, na nossa condição de seres ligados à contingência ${ }^{33}$.

A parte qüiditativa ou essencial de alguma coisa deve estar na própria coisa (in re). Esta opinião vai de encontro às concepções de cunho platônico-agostiniano. E para refutar esta opinião, a base do pensamento de Scotus é a improbabilidade da dupla negação num mesmo lugar (ou coisa): " pode ser e não ser'." 34

As opiniões de Scotus estão mais voltadas para Aristóteles e Avicena do que para o platonismo e o averroísmo latino. Duns Scotus praticamente forma a sua concepção de essência, universalidade e a ação do intelecto com base em Avicena. $\mathrm{O}$ princípio avicenista coloca a dualidade universal e a essência na análise do ser. $\mathrm{O}$ universal é aquilo que é predicado de muitos. Em contraposição, temos os particulares que devem ser diferenciados por meio da sua essência: "a [essência] não pode ser pensada senão como pertencente a ela somente" 35. A essência como algo único, próprio, incorruptível e ligado ao individual é uma idéia de cunho avicenista apropriada por Scotus. A teoria da indiferença de Avicena é o princípio que serve de base para que concepção escotista do particular por si mesmo se construa. A indiferença também é chamada de "cavalidade" 36, isto é, em referência ao exemplo do cavalo que significa o último estado possível em que uma coisa é. Ao mesmo tempo, o ser individual possui sua própria essência, ela não é universal nem particular ligado somente às espécies. Como Avicena diz: "No seu [modo de] existência, ele não é nem gênero ou espécie, nem individual ou muitos. Mas, no seu [modo de] existência ele é unicamente animal ou unicamente homem" ${ }^{37}$.

O que o Doutor Sutil, fundamentado em Avicena, pretende é afirmar a não admissão de que uma coisa possa ser e não ser ao mesmo tempo pela definição de

\footnotetext{
humanos herdou esta condição.

34 "potest esse et non esse". Quaes. Super, L. VII, Q.16, 18.

${ }^{35}$ AVICENNA, Methaphysics. Livro 5, Capítulo 1, (5).

${ }^{36}$ AVICENNA, Methaphysics. Livro 5, Capítulo 1, (4).

${ }^{37}$ AVICENNA, Methaphysics. Livro 5, Capítulo 1, (14).
}

${ }^{31}$ Utrum in rebus materialibus materia sit pars quiditas rei. Quaes. Super, L. VII, Q.16, 1.

32 'quod quid est' est principium cognocendi illud cuius est. Quaes. Super, L. VII, Q.16, 6.

33 Como teólogo, Duns Scotus associa o pro statu isto com a condição humana de caído, ou seja, a situação dos seres após a queda em pecado e a seguida expulsão de Adão e Eva do paraíso conforme a descrição do livro do Gênesis. Por conseqüência, a humanidade como descendente dos dois primeiros 
"quiditas", isto é, da essência. Com isto, o ato de ser e não ser ao mesmo tempo abre caminho para a corruptibilidade da essência. Assim, se a materialidade é o composto que faz com que algo seja algo, jamais podemos admitir que ela possa ser mudada ou corrompida. Deste modo, o "potest esse et non esse" sustentada pelos platônicoagostinianos e as opiniões de Aristóteles são antagônicas como quer Duns Scotus: "Se, por sua vez, a matéria é o princípio pelo qual algo 'pode ser e não ser', se ela fosse parte da definição, a 'quod quid est' poderia, por si, gerar-se e corromper-se, contra o Filósofo" ${ }^{38}$.

No argumento de Scotus, a opinião de Platão separa a forma e a matéria na definição: "este ser como matéria, aquele como forma" ${ }^{39}$. Nesta parte, a dissociação forma e matéria, segundo o argumento platônico, se dá em relação à idéia (idea) das coisas separadas das coisas materiais. Assim, segundo este pensamento, a idéia não é definível porque é somente forma ${ }^{40}$ e se separa da matéria. O Doctor Subtilis é veemente contra esta opinião. Não podemos separar as coisas materiais das formas. Se, porventura, admitirmos que a forma não possa ser definível e, naturalmente, separada, não há a definição integral da coisa investigada. Desta forma, Duns Scotus diz:

O que é definido verdadeiro possui forma e matéria e ambas são pertencentes à definição. (...) Portanto, desta feita, todas as partes precisamente exprimem toda a coisa. Deste modo, todas as partes são a razão da coisa (...). Mas é perfeitamente impossível conhecer a coisa sem conhecer a sua matéria. Assim, a forma não é toda a sua qüididade que, por sua vez, possui matéria ${ }^{41}$.

A refutação do pensamento platônico revela que a argumentação escotista leva em conta a razão material das coisas. Uma coisa natural é por definição um composto (compositum) que une a matéria e forma, mas pela análise (definição) escotista não se pode separar estas da qüididade. A concepção do composto é a nãodissociação de um ser ou entidade. E não só isto, mas por si existente ${ }^{42}$.

A materialidade como fundamento do ser natural traz novamente a possibilidade de comparação entre aquilo que é propriamente da essência e o que é universal. O que é essencialmente caracterizado é chamado por Duns Scotus de "quid", ou seja, um o que é. O universal jamais pode ser um "quid". Assim, o "quid" de Duns Scotus tem por características ${ }^{43}$ : a) não ser universal pelo fato de que ele não é

\footnotetext{
${ }^{38} \mathrm{Si}$, ergo materia sit principium per quod aliquid 'potest esse et non esse', si esset definitionis, 'quod quid est' posset generari et per se corrumpi, contra Philosophum. Quaes. Super, L. VII, Q.16, 19.

39 "hoc esse ut materiam, illud ut formam". Quaes. Super, L. VII, Q.16, 21.

${ }^{40}$ Quaes. Super, L. VII, Q.16, 21.

${ }^{41}$ Quod definitur vere habet materiam et formam, et utrumque pertinet ad definitionem. (...) Sicut ergo omnes partes praecise exprimunt totam rem, ita omnes partes rationis rationem rei. (...) ergo forma non est tota quiditas eius quod habet materiam. Quaes. Super, L. VII, Q.16, 21-23.

${ }^{42}$ Quaes. Super, L. VII, Q.16, 25-26.

${ }^{43}$ Quaes. Super, L. VII, Q.16, 35-38.
} 
"simul totum" (ao mesmo tempo em todos) enquanto tal; b) ele possui partes qüiditativas suas e não uma simples qüididade geral; c) o "quid" é aquilo que inclui algo além da qüididade específica.

O traço mais original de Duns Scotus talvez esteja neste momento: a admissão de que exista uma característica entre os singulares de algo de modo que exceda ao número quando há a divisão das espécies. A espécie não é o último critério para a construção dos singulares, ou seja, os diversos números que as espécies possuem. Para a construção do particular último, na divisão das espécies, é necessário ver aquilo que é também próprio das espécies e esta possua identidade com as demais ${ }^{44}$. Porém o definidor será aquilo que está além do número.

Anteriormente, na definição do Doctor Subtilis, a unidade que vai além da numérica é tratada no texto da Lectura e na Opus Oxoniense. Mas o desenvolvimento da questão que envolve a essência e a unidade só será tratado com maior precisão no livro Quaestiones Super Libros Metaphisycorum Aristotelis. Com isto, o estudo da unidade é fundamental para que a essência seja entendida. A singularidade é formada em um tripé: a positividade ou algo positivo na própria coisa (aliquid positivum), a substância material que confere realidade às coisas e a unidade da natureza da coisa (unitas naturae rei).

No processo de formação da unidade singular é necessário que ela antes seja identificada por algumas características: i) "Primeiro, desta forma, mostro que a natureza específica a partir de algo positivo é contraída a partir da singularidade; ii) a idéia de que a singularidade seja proporcional nas divisões é diferente da unidade menor do que o número "porque a unidade da natureza é unidade menor do que essa singularidade da qual é da unidade numeral" 45; iii) esta terceira relação está entre a singularidade e as espécies:

Essa, por outro lado, entidade faz "o uno por si" por meio da natureza específica, porque acima está provado que o indivíduo por si é por si um, não por meio da unidade dos outros gêneros; com isso, é seguido que a natureza específica determina a partir de algo positivo e a partir da existência (ou da essência) deste indivíduo. ${ }^{46}$

O traço distintivo do Doctor Subtilis em sua teoria da individualidade e da essência é o não desligamento das coisas materiais. Se um indivíduo "unum per se" pode ser admitido, ele necessariamente terá que corresponder com a sua realidade

\footnotetext{
${ }^{44}$ Quaes. Super, L. VII, Q.16, 39.

${ }^{45}$ quia unitas naturae minor est unitas quam sit ista sungularitas quae est unitas numeralis. Lectura II, dist. 3, pars 1 q. 5-6, 166.

46 Ista autem entitas facit 'per se unum' cum natura specifica, quia supra probatum est quod individuum est per se unum, non per unitatem alterius generis; ergo sequitur quod natura specifica determinetur per aliquid positivum ad essendum hoc individuum. Lectura II, dist. 3, pars 1 q. 5-6, 166. A palavra "essendum" admite duas possibilidades de tradução, mas com dois fins: uma pode ser traduzida por essências ou das essências mesmo e outra como existência. Desta forma, ambas imprimirão um mesmo sentido à essência como meio "sine qua non" para a existência.
}

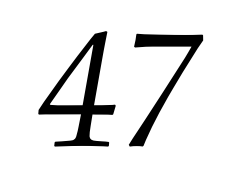


material. Em suma, um ente real. Contra qualquer perspectiva de sofismas sobre o ente real, Duns Scotus acredita que sem a realidade da entidade para se chegar à sua essência, ou qualquer outro tipo de característica que o faça um a partir de si, tudo não passa de falácia.

Desta forma, Scotus define que, no que diz respeito à realidade em relação à qüididade se dá: "porque a realidade específica constitui de um composto (de quem é parte) no ser qüiditativo, porque a própria entidade da espécie qüiditativa, essa realidade do indivíduo, por outro lado, é a primeira diferença sob toda entidade qüiditativa" 47 Aquilo que Scotus chama composto é único, mas pode ser subdividido em partes, mas não partes por si, porém para um entendimento de cada parte: como exemplo, a forma, matéria, substância específica ou a qüididade. A realidade é mais uma das partes, mas se o "quid" for investigado quem ele é em realidade, jamais será pelas partes, mas pelo composto completo ${ }^{48}$.

Entre as espécies, fato é que se podem admitir subdivisões. Caso contrário, sem a divisão das espécies em partes subjetivas, haveria somente um indivíduo da espécie. Na geração ficaríamos somente com um indivíduo específico herdeiro direto, porém um novo gerado, dos gêneros. Contudo a divisão, para Scotus, possui algo mais do que um simples conhecimento do número que está ligado à quantidade (quanta). As espécies geram novos indivíduos essenciais "por si", com materialidade própria.

Na divisão que se origina os individuais, a diferença individual é o último fundamento da individualidade. Este indivíduo é unificado e não pode ser dividido em partes subjetivas, ao modelo dos gêneros e das espécies. Com isto podemos entender esta parte através do exemplo dado por Peter King:

Um gênero como 'animal' é dividido em partes subjetivas, para suas próprias partes, e.g., a espécie humana, é tal qual que 'humanos são animais", é uma verdade, da mesma forma uma espécie, por suas próprias partes, e.g., o Sócrates individual, da mesma forma 'Sócrates é humano' e é uma verdade. Porém Sócrates não pode ser dividido segundo esta via. Obviamente ele pode ser 'dividido' a partir de material heterogêneo por meio de partes integrais; podemos usar a mão de Sócrates como exemplo. Mas as mãos não são partes subjetivas: ‘ a mão de Sócrates é Sócrates', isto não é verdade. (...) A divisão final advindo da última comunidade gera alguma coisa indivisível, o indivíduo (etimologicamente 'in-dividuum') e a

\footnotetext{
${ }^{47}$ Quia illa realitas specifica constituit compositum (cuius est pars) in esse quiditativo, quia ipsa est entitas qwuaedam quiditativa, ista autem realitas individui est primo diversa ab omni entitate quiditativa. Ordinatio II, dist. 3, pars 1, q5-6, 181.

${ }^{48}$ Quaes. Super, L. VII, Q.8, 25.
} 
diferença individual é em si mesma indecomponível e, a partir daí, o último definitivo ${ }^{49}$.

Nas obras de Scotus encontram-se outros critérios para entendermos o indivíduo e a sua essência: a homogeneidade e a heterogeneidade. Entre a homogeneidade e a heterogeneidade se encontra aquilo que pode ou não ser dividido em partes subjetivas. Evidente que um último indivíduo real não pode ser subdividido em partes subjetivas e ser um novo ser real. Desta forma, ser homogêneo é ser também por si. No entanto, a heterogeneidade e a homogeneidade na construção de um ser em si, expressa por Duns Scotus, não encontram uma explicação clara em suas obras. Apesar disto, Scotus se expressa desta forma:

Assim, por sua vez, supondo a prova pela conclusão: investigamos que o 'quid' seja aquilo no indivíduo pelo qual, a partir de si, rejeita a divisão em tais partes subjetivas, ou seja, qualquer que seja um próprio. Por outro lado não se nega que o próprio possa ser dividido em partes essenciais, semelhantemente em integrais heterogêneas e homogêneas; às vezes, porém, nenhuma parte, também a homogênea, é a própria divisão, embora a mesma espécie predicada pela parte dividida da qual é a predicada de todos ${ }^{50}$.

Os antecessores de Scotus, com relação às espécies, admitiam a singularidade como parte da separação numeral relativa da divisão das espécies. Grande parte dos filósofos anteriores a Scotus baseavam-se na "Árvore Porfiriana" sobre as categorias e as divisões propostas por Porfírio (c.232- c.304) na sua obra Isagoge conhecida também como Introdução às Categorias a qual comentava o livro Dos Tópicos de Aristóteles. Nesta obra, Porfírio, estabeleceu uma divisão além dos quatro predicáveis propostos nos textos lógicos do Estagirita (gênero, definição, acidente e próprio). O filósofo neo-platônico, acrescentou a idéia de diferença o que foi fundamental para a lógica, já que se redefiniu a idéia de predicado ${ }^{51}$. Com isso, a “Árvore de Porfírio" é construída assim:

\footnotetext{
${ }^{49}$ KING, Peter. Scotus on singular essenses. In: Medioevo 30 (2005), 111-137. Disponível no site pessoal do autor da University of Toronto, Canada: <http://individual.utoronto.ca/pking/articles.html > acesso em 29 de março de 2009. p. 122

${ }^{50}$ Sic ergo, supponendo conclusionem probatam, quaerimus quid sit illud in individuo per quod sibi repugnat diviosio in partes subiecjetivas tales, scilicet quarum quaelibet sit ipsum. Non enim negatur ipsum posse dividi in partes essentiales, similiter in integrales heterogeneas et homogeneas; quandoque tamem nulla pars, etiam homogenea, est ipsum divisum, licet eadem species praedicetur ibi de parte divisa quae prius paedicabatur de toto. Quaes. Super, L. VII, Q.13, 118.

${ }^{51}$ MOURA, Odilão. Sumário dos Capítulos e anotações ao texto do 'De ente et essentia”. In: SANTO TOMÁS DE AQUINO. O Ente e a Essência. Introdução e notas de D. Odilão Moura, OSB. Texto Latino e Português. Rio de Janeiro: Presença, 1981. p.131-133.
}

\section{9}




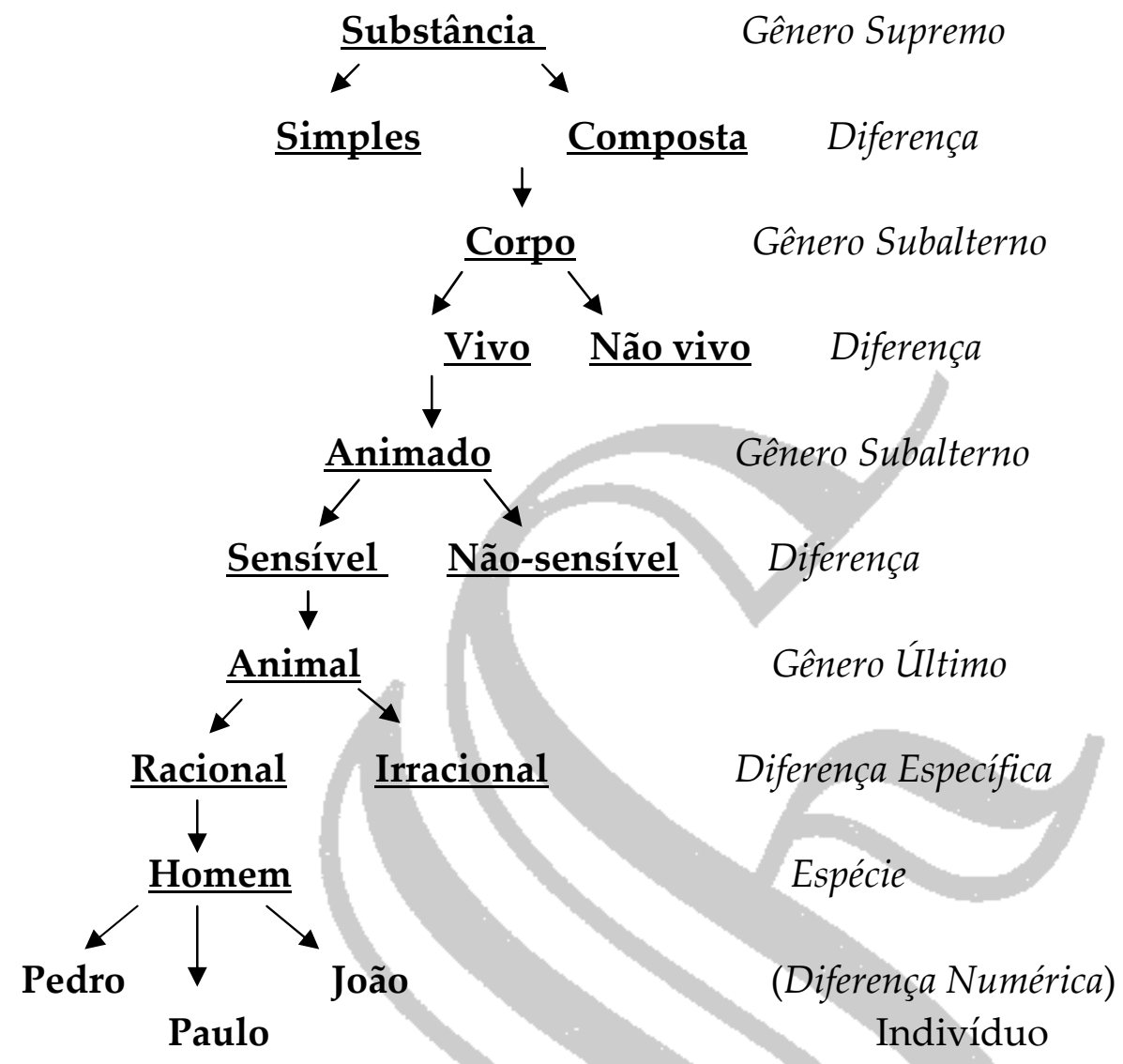

Muitos dos lógicos do século XII e também os aristotélicos, posteriormente à entrada das obras metafísicas de Aristóteles, do século XIII, adotavam tal modelo como explicação para as categorias. Na concepção de Porfírio, o predicado era entendido como a própria essência e, às vezes, confundida com o acidente ${ }^{52}$. Diante disto, os limites da predicação, do acidente e da essência não estavam bem delimitados neste modelo. $\mathrm{Na}$ "Árvore de Porfírio" já se admitia o indivíduo último além da divisão da espécie, mas, em relação à essência, ainda muito indistinto. Duns Scotus fez diferente: "essencializou" o último indivíduo advindo da divisão numeral das espécies.

Com efeito, o Doctor Subtilis faz a distinção: estabelece a idéia de unidade real e unidade numeral. A unidade numeral é somente identificável de forma geral, isto é, sabemos que existem as singularidades numerais, mas não podemos defini-las de forma real. Por outro lado, no entendimento de Cesar Ribas, a unidade real é aquilo que foge a qualquer ação puramente intelectiva (ligada aos universais e aos gerais), ela é por si mesma identificável por ser um grau que excede à generalidade do número ${ }^{53}$. Desta maneira, Duns Scotus define a unidade real:

\footnotetext{
52 MOURA, Odilão. Sumário dos Capítulos e anotações ao texto do 'De ente et essentia". In: SANTO TOMÁS DE AQUINO. O Ente e a Essência. Rio de Janeiro: Presença, 1981. p. 132. A "Árvore de Porfírio" na qual nos baseamos foi retirada da mesma página dos comentários de D. Odilão Moura.

${ }^{53}$ CEZAR, Cesar Ribas. O conhecimento abstrativo de Duns Scoto. Porto Alegre: EDIPUCRS, 1996, p.2627.
} 
Além disso, qualquer unidade real, própria e suficiente, é menor do que a unidade numeral, aquele que não é de si uno na unidade numeral (ou não é de si isto); mas da natureza presente na pedra, é de unidade própria, real ou suficiente, menor do que a unidade numeral, portanto etc. ${ }^{54}$

Nas espécies podemos encontrar aquilo que é claro e por si matéria, mas não um individual último. Porém entre as espécies há um sentido de comunidade maior do que propriamente os indivíduos. Se descendo do mais geral de todos, ou seja, dos gêneros para as espécies, será possível visualizar um estreitamento das características se aproximando mais do individual, a espécie não é, portanto, a última categoria na definição dos particulares.

Existe algo mais além da variação numeral específica. Se, portanto, pode-se admitir uma essência específica, ela terá mais um sentido de comunidade, um "simul totius" entre os indivíduos da mesma espécie, do que um grau último de atualização. Com a possibilidade de pensar a particularidade ou singularidade além da separação das espécies em números, Scotus levanta a possibilidade de acrescentar algo mais como definição, mas não à qüididade da espécie. Aquilo que excede não é acidental nas palavras do Doutor Sutil:

Nenhuma, no entanto, matéria acidental é a partir da qüididade da espécie, embora seja impropriamente tomada por alguns 'ao mesmo tempo em todos' propriamente tomados, isto é, a partir de sua razão tal qual. Por esta razão, aquilo adicionado à qüididade propriamente dita não a faz um conceito uno por se. $^{55}$

Neste sentido, a qüididade ou essência não pode ser corrompida em nenhuma maneira.

Nada pode ser acrescentado a ela quer acidental ou outra coisa. Étienne Gilson entende que este processo aplica-se como privação e ao mesmo tempo positivação. Privação pelo fato de que nada pode ser adicionado à qüididade. E a positivação é entendida a partir de que só pode dizer alguma coisa da última realidade do ser, senão por meio de algo contido no próprio ser (afirmação) ${ }^{56}$.

Se a qüididade se permitisse adicionar algo ela poderia "ser e não ser" (potest esse et no esse), o que fere o princípio de ser um "quid" por sua própria razão. Este é

\footnotetext{
${ }^{54}$ Praetera, cuiuscumque unitas realis, propria et sufficiens, est minor unitate numerali, illud non est de se unum unitate numerali (sive non est de se hoc); sed exsistentis in isto lapide, est unitas propria, realis sive sufficiens, minor unitate numerali; igitur etc. Ordinatio II, d.3, p. 1, q.1, 8 .

55 Nulla autem materia accdentalis est de quiditate specei, licet aliqua sit de quiditate improprie sumpta 'simul totius' proprie sumpti, hoc est, de ratione eius tali quali, quia illud additum quiditati proprie dictae non facit cum ipsa unum per se conceptum. Quaes. Super, L. VII, Q.16, 40.

${ }^{56}$ GILSON, Étienne. Jean Duns Scot... op. cit., p. 452.
}

\section{1}


um ponto em que, segundo o Doctor Subtilis, Aristóteles e Platão discordam. Em Platão, como nos apresenta Duns Scotus, a forma é o "quod quid rei" 57, isto é, o princípio, separado das coisas, da essência. Já em Aristóteles há a concretização material do composto (forma mais matéria) que é o "quod quid est rei" que "mas, além disso, requer a matéria nas coisas materiais" 58.

A matéria como parte da qüididade faz com que ela assuma a função a partir de si mesma, pois a essência é por si mesma caracterizável. O fato de Duns Scotus pensar a "quod quid est" além das espécies o faz diferente de seus antecessores. Se o pensamento aristotélico, principalmente Tomás de Aquino, admite que a divisão das espécies gere particulares em número somente; Duns Scotus pensa que o número é insuficiente para dar conta do que de fato pode ser a última singularidade, isto é, um genuíno "per se". Existe algo além da espécie ${ }^{59}$ e dos números como Scotus diz:

Mas possuir uma matéria individual não é o mesmo com a 'quod quid est' das espécies, e esta por causa da matéria individual, do qual

${ }^{57}$ No texto de Duns Scotus existem duas maneiras de se ver a essência e somente uma delas é compartilhada por ele. A palavra "quod quid" gramaticalmente no latim não se pode construir, mas implica a idéia de "o que é daquilo que é" sem uma correspondência real e sem entidade real. Agora, o "quod quid est rei" é a análise que vê a essência na coisa sendo ela uma entidade real e material. Scotus compartilha desta última, pois ele recusa qualquer separação não material da qüididade: a coisa real tem que corresponder com a coisa qüiditativa.

${ }^{58}$ Sed etiam requitur materia in rebus materialibus. Quaes. Super, L. VII, Q.16, 42.

${ }^{59}$ A idéia de além das espécies (ultra speciem) pode gerar confusões interpretativas que nos induzem a pensar como aquém das espécies. Em primeiro lugar, "aquém" (em latim citra) em nenhum momento é citado nos textos de Duns Scotus estudados por nós. A interpretação como aquém das espécies é o meio mais obvio de entender por uma leitura desavisada. Isto se comprova por dois motivos: primeiro, se dos gêneros para as espécies existe a diminuição da generalização, ou seja, ao mesmo tempo em que cada vez mais temos um individual, a tendência do número também é diminuir. Nos gêneros existem mais números de seres do que nas espécies e, assim, de forma decrescente até se chegar ao último. Segundo, se a relação for meramente numeral, naturalmente, ela será aquém das espécies (citra speciem), contudo não é o que Duns Scotus queria dizer. A idéia de além (ultra) é mais plausível, pois é uma afirmação do próprio punho de Scotus. Além disso, interpretar a idéia de "além das espécies" é levar em conta o conjunto das afirmações escotistas e olhar com mais aprofundamento o seu pensamento. O Doctor Subtilis rejeita qualquer tipo de relação meramente numeral nas divisões das espécies para chegarmos à essência. Como a última individualidade não é uma relação meramente numeral, ela está além do número individual das espécies. Com isso, o critério de Scotus não é quantitativo mais qualitativo, pois às essências não interessam as quantidades, mas as qualidades. Desta forma, é uma relação decrescente: gêneros (animal) para as espécies (homem) as espécies dividem em Sócrates, Platão etc., em suma, individuais concretos e últimos. Por sua vez, Sócrates será a partir dele mesmo e além das espécies (ultra speciem). Se Sócrates fosse aquém, teríamos um retrocesso nas ordens das categorias o que é inadmissível quando falamos de qualidade. Em outras obras encontramos também esta preocupação em Scotus: "algo é unidade real se é além da unidade numeral" (est aliqua realis praeter unitatem numeralem) Lectura II, disti. 3, pars 1, q. 1, 25. Além do termo latino ultra, Scotus usa praeter (além de) que nos induz à mesma observação: que a unidade numeral não é suficiente, isto é, precisa-se de algo que exceda (além) da unidade numérica "ultra (praeter) unitatem numeralem". 
inclui o indivíduo, e que não é incluído em espécie" ${ }^{60}$. Ou em outro trecho: “Desta forma, é dito que a matéria não é a partir de sua substância o princípio da transmutação de outro, mas a razão das privações relacionadas a ela. ${ }^{61}$

A matéria que existe nos particulares é importante para que ela seja privada de algo mais. Privar é trazer para o "quid" sua própria materialidade. Se a materialidade é fundamental para os particulares, a privação como entende Scotus, não pode ser dita segundo os acidentes. Quando Duns Scotus vê a possibilidade de algo ser além do número específico e ser a razão da máxima particularidade, o Doutor Sutil intenciona dizer que o particular não é algo que parte de fora (ex aliquo) e é adicionado, mas uma razão que está intrinsecamente relacionada ao próprio "quid". Esta é a máxima que envolve o particular e a geração desta essência. A geração da qüididade é investigada com base na correspondência entre a qüididade e aquilo que é enquanto um "quid" 62.

A geração da essência dos particulares, na opinião de Scotus, pode se dar de duas formas: a) "per accidens" com base nos "ens per accidens", isto é, uma relação puramente acidental; b) e aquilo que é gerado "per se" em que tem a seguinte base: " 'quod quid erat' da forma não é gerada, nem 'quod quid erat' das espécies, mas 'quod quid erat' um ser singular gerado por si, segundo o singular"63. A proposição gerativa com base nos acidentes não é possível, pois o acidente não é substância. Com isso temos a premissa: "a qüididade do homem branco é a mesma da do homem branco" 64 a característica de branco não pode ser o meio definidor, pois a brancura não é substância, pois ela está sob a razão do homem.

Por outro lado, a qüididade é formada e "dita segundo si" dependente de um sujeito ao qual analisaremos a sua essência. Porém, é necessária, na geração, alguma função intelectiva? Segundo Duns Scotus, a parte intelectiva é fundamental para que possamos apreender as idéias gerais ( $a b$ intelectum) sobre o ser, porém a "quod quid est", enquanto parte da coisa, possui seu fundamento "in re": "onde a 'quod quid est' é a mesma que a coisa, não depende dos predicados 'in quid' nem sobre o intelecto" 65.

A função intelectiva tem por objetivo separar a realidade que pode ser pensada em sua generalidade contrapondo à particularidade que atua no próprio objeto. Com a sentença "homem é homem" (homo est homo), citada pelo Doutor Sutil,

\footnotetext{
${ }^{60}$ Sed habens materiam individualem no est idem cum 'quod quid est' speciei, et hoc propter materiam individualem, quae includitur in individuo, quae non includitur in specie" Quaes. Super, L. VII, Q.16, 45.

${ }^{61}$ Ideo dicitur quod materia no de sua substancia est principium transmutandi ab alio, sed ratione privationis adiunctae. Quaes. Super, L. VII, Q.16, 49.

62 Utrum 'quod quid est' sit idem cum eo cuius est. Quaes. Super, L. VII, Q.7, 1.

63 'quod quid erat' fromae non generatur, nec 'quod quid erat' especei, sed 'quod quid' esse singularis generatur per se, sicut singulare. Quaes. Super, L. VII, Q.7, 7.

${ }^{64}$ Quaes. Super, L. VII, Q.7, 9.

${ }^{65}$ Unde 'quod quid est' est idem quod res, nec dependet a praeditatis in quid nec ab intellectu. Quaes. Super, L. VII, Q.7, 16.
} 
abre-se o caminho para duas possibilidades: a parte intelectiva e a parte qüiditativa. A identidade do homem é a primeira apreensão da sentença e o primeiro em si considerado com base na coisa, mas com a função intelectiva como preponderante. Por outro lado, a qüididade é em segundo modo, é por si na coisa, logo foge da alçada do intelecto: "o homem será a sua mesma qüididade além de todo o intelecto" 66 . Quando a qüididade é construída com base no próprio ser, in re, ela não pode ser definível, unicamente, só pelo intelecto e nem pelos predicamentos (acidentes). Mas somente pela coisa. Em uma construção de base lógica, como exemplo, Duns Scotus definiu a "quod quid est" em sua singularidade como genitivo e não como nominativo. Ele quis dizer que a essência atua não como sujeito (nominativo), mas como algo que é restrito à posse, ou seja, aquilo que é do sujeito (genitivo) ${ }^{67}$.

Deste modo, a "quod quid est" é tratada em três níveis: o intelecto, a lógica e a coisa. Porém a coisa é o que se dá de maneira realista e o verdadeiro fundamento da essência deste "quid". Na geração com base na realidade específica é necessário ir além da natureza específica, na medida em que esta natureza específica seja caracterizada como "uma substancia por si". Deste modo, é fundamental que se acrescente algo à natureza da espécie, não acidental, e "assim se pode possuir a própria 'quod quid'" 68.

Sobre possuir essência ou "quod quid est", o critério que Scotus apresenta é ser propriamente o que ele é. Isto é, trazer para a entidade nada de outro, quer acidentes ou alguma outra característica que ascenda do particular para o geral, mas nele mesmo $^{69}$.

Diante disto, encontra-se a relação do "uno" com os "gêneros". Mas não uma aplicação que estenda dos gêneros para os singulares. Por esta razão, Duns Scotus deixa claro que o conhecimento da substância qüiditativa obedece a critérios: somente por meio dos particulares é possível conhecer a essência do "quid". Assim, o Doutor Sutil diz:

A 'quod quid est', por esta razão, é substância de qualquer, e estendendo substância a todos os gêneros dos seres. Caso contrário, nada dito segundo si será um ente formalmente a partir de si e nem conhecível. Por que não é algum ente formalmente a não ser que de si haja 'quod quid est'. Da mesma forma, não é conhecível, porque de modo perfeito ' conhecer o cada um é conhecer o próprio' e, desta feita, é conhecer o seu 'quod quid est.'70

\footnotetext{
${ }^{66}$ Homo erit idem quiditati suae praeter omnem intellectum. Quaes. Super, L. VII, Q.7, 16.

${ }^{67}$ Quaes. Super, L. VII, Q.7, 17.

${ }^{68}$ et tunc potest habere proprium 'quod quid'. Quaes. Super, L. VII, Q.7, 21.

${ }^{69}$ Quaes. Super, L. VII, Q.7, 22.

70 'Quod quid est' ergo est substantia cuiuscumque, extendendo 'substantia' ad omne genus entium. Alioquin nihil dictum secundum se erit ens formaliter de se, nec scibile. Quia non est aliquid ens formaliter nisi quia sibi inest 'quod quid est'. Similiter nec scibile, quia perfecte "scire unumquodque est scire ipsum', et hoc est scire suum 'quod quid est'. Quaes. Super, L. VII, Q.7, 22.
}

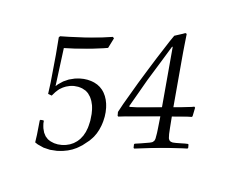


Assim, podemos compreender que, como exemplifica Duns Scotus, a coisa (rem) e a qüididade (quiditas) são elas respectivamente $\boldsymbol{A}$ e $\boldsymbol{B}$. $\boldsymbol{B}$ é um ente e não é $\boldsymbol{A}$ e, assim, é outro. Com isso, $\boldsymbol{B}$ possui "quod quid est". Com base neste exemplo vemos que a explicação dada é que a "quod quid est" é algo próprio de si e não de outros. Mas este próprio é o grau último de singularidade, isto é, ela excede ao gênero, à espécie e a diferença numeral advinda da multidão gerada a partir das espécies.

O que pretende Scotus é separar e conferir a singularidade um caráter especial mediante aos números resultantes da divisão das espécies. Existe algo além da matéria dos gêneros e das espécies. Esta é a matéria individual. Isto se confirma no dizer escotista: "digo que a 'quod quid est' da espécie não é a mesma conjunta com os singulares porque adiciona algo além a matéria individual. Todavia, com a sua própria "quod quid est" o singular é o mesmo "71.

O papel da matéria individual é a sua função gerativa dos singulares adjunta à "quod quid est". Com isso, quando Sócrates é gerado, a sua "quod quid est" é gerada "per se" de modo que o critério gerativo das espécies se aplica ao homem enquanto espécie. Contudo aos homens particulares a geração de um individual, como Sócrates, é a partir da sua "quod quid est". Mas cabe uma ressalva: ainda que o termo geração seja usado, a "quod quid est" não pode ser considerada a partir da sua geração, mas da razão deste algo (aliquid) ${ }^{72}$.

Como nos mostra Peter King, na medida em que a "quod quid est" é traçada por Duns Scotus, ela assume características de "essência singular" 73. Do que até aqui foi exposto, o ser em sua apreensão última, isto é, "quid" possui algo que o faz mais do que a sua natureza humana e é algo particular além das espécies. Ele possui uma essência própria por si mesma e que não pode ser mais de ninguém. No exemplo de Scotus, Sócrates é, enfim, sua essência singular.

O ponto norteador da perpectiva do Doutor Sutil é a particularidade e o "per $s e$ " como noções básicas para se chegar à essência ou qüididade. A concepção de algo "per se" é a maneira pela qual a particularidade é construída no individual último. Além disso, um "quid", a partir de si mesmo, abre para a questão: sua natureza é, verdadeiramente, a partir de si ou por algo extrínseco ${ }^{74}$ Como resposta, em um primeiro momento, existe a oposição entre o que é "isto" (haec) e à comunidade (universalia). Neste princípio, vemos que o conceito de "isto" pode ser apreendido segundo a sua natureza intelectiva ou não. A primeira definição de algo está ligada à sua generalidade e, por sua vez, a ação intelectiva. Por outro lado, aquilo que passa a ser definido com clareza, ou seja, o indivíduo último é necessariamente concreto com sua "quod quid est". Entre os particulares não se pode admitir alguma ação intelectiva efetiva como primeira apreensão ou como a única forma de defini-los.

\footnotetext{
${ }^{71}$ Dico quod "quod quid est" specei non est idem cum singulari, quia addit aliquid ultra speciem, scilicet materiam individualem. Tamen cum suo próprio "quod quid est" singulare est idem. Quaes. Super, L. VII, Q.7, 27.

72 Quaes. Super, L. VII, Q.7, 28-31.

${ }^{73}$ KING, Peter. Scotus on singular essences... op. cit., p. 111-137.

${ }^{74}$ Quaes. Super, L. VII, Q.13, 1.
} 
O ser geral e indefinido, como primeira apreensão, é a base para a construção de qualquer ser quando nos direcionamos para uma determinada realidade. Entre o ser geral e as coisas reais existe uma diferença definível: o intelecto apreende, em uma primeira análise, objetos simples e também o Ser mais simples de todos.

Desta maneira, este Ser, Duns Scotus chamou de Deus. Mas também para a vida contingencial, o ser apreendido no intelecto é útil. Gilson definiu que em Duns Scotus as qüididades podem também passar pela noção do intelecto, isto é, a ação intelectiva consegue apreender as qüididades das coisas materiais. Esta é uma possibilidade, ainda segundo Gilson, que o Doctor Subtilis desenvolve em dois níveis: a) a qüididade dos seres simples é identificável intelectualmente, pois os seres simples são a sua própria qüididade 75 ; b) Por outro lado, quando falamos de "ente real" temos que associar a realidade da coisa, mas a base formativa é intelectual. Porém a essência do ente real não está subordinada ao intelecto o que, assim, relega ao ser real a função de qüididade por si mesmo ${ }^{76}$. Entenda-se ente real aquele que está em nossa realidade ou estado atual (pro statu isto).

Com base nas afirmações anteriores, Étienne Gilson conclui:

Duns Escoto, percebe claramente a objeção fundamental que ameaça tal conclusão: ela implica a univocidade do ser; pois, se o intelecto tem no ser seu objeto próprio, ele deve poder assimilá-lo por um ato único, e conseqüentemente conhecê-lo no mesmo sentido, qualquer que seja a espécie do ser apreendido. ${ }^{77}$

Desta forma, o que é ser formado no intelecto pode servir de princípio para ao conhecimento real e individual dos demais entes contingenciais. Mas não uma subordinação, ou seja, ainda existe uma diferença clara estabelecida por Scotus entre o que é necessariamente objeto do intelecto e o que é real na coisa. O indivíduo que está além das espécies deve conter unidade real e não pode ser meramente pensado.

\footnotetext{
75 O ser mais simples, desde Tomás de Aquino (De ente et essentia, Cap. V,49), é tratado de forma indubitável como Deus. Duns Scotus, porém, trata da substância simples, em um primeiro momento, de forma geral sem dar nomes. Este princípio considerado pelo Doctor Subtilis relaciona-se da idéia de primeira apreensão do intelecto: o ente enquanto ente (ens in quantum ens) sem fazer distinção das coisas. Peter King explica assim: "Deus, anjos e substâncias são todos considerados na metafísica como seres, pois são seres, mas eles não são mais do que objetos primários da metafísica" (KING, Peter. Scotus on metaphysics. In: WILLIANS, Thomas (Ed.). The Cambridge Companion to Duns Scotus. Cambridge: University Cambridge Press, 2003. p. 17.) Contudo, existe a ordenação dos seres por critérios relacionados ao seu grau de completude. Duns Scotus, portanto, prefere não dar o nome, em princípio, da substância simples de Deus devido às suas investigações sobre qual seria o objeto da metafísica. Suas conclusões são longas e complexas sendo aqui inapropriado discuti-las. Mas os textos nos quais encontraremos todas estas conclusões são: Quaes. Super, L.I, Prologus. e Quaes. Super, L.I, Quaestio 1 et 2.

${ }^{76}$ GILSON, Étienne. Avicena o ponto de partida de Duns Escoto. In: Idem. Por que São Tomás criticou Santo Agostinho/ Avicena o ponto de partida de Duns Escoto. São Paulo: Paulus, 2010. p.137.

${ }^{77}$ Idem, p. 140.
} 
Neste indivíduo já constituído, não é, portanto, aplicada a função intelectiva que parte do princípio avicenista da generalidade de um ser ou do ente enquanto ente.

Para isto, Scotus apresenta a sua solução diante do problema de Avicena: "porque qualquer unidade real própria é menor do que a unidade numeral. Aquilo que não é a partir de si unidade numeral ou não é a causa suficiente de tal unidade ou não é de si isto." 78 Em ordem para a singularidade, fica-se claro que aquilo que é uma unidade não deve ser maior nem menor do que sua própria unidade. Com isto, esta unidade de singularidade última tem que ser suficiente em si, buscar as razões de singularidade nela mesma e não contradizer-se (non potest esse et non esse).

Claramente o "quid" e o "quod est" uno por si terão unidade real como afirma o Doutor Sutil: "nenhuma unidade real da natureza é menor do que a heceidade, nem a unidade real é supostamente menor." 79 Neste sentido, a unidade real está pari passu com a sua heceidade (haecceitas) ${ }^{80}$, já que, a heceidade é a menor parte e a individualidade máxima possível do "quid".

Nesta medida, podemos estabelecer igualdades na realidade do objeto. Com a constituição da realidade em sua individualidade última e a não admissão de mais divisões neste particular, João Duns Scotus propõe a idéia que aquilo que é

\footnotetext{
${ }^{78}$ quia cuiuscumque propria unitas realis est minor unitate numerali, illud non est de se unum unitate numerali, sive no est sufficiens causa talis unitatis, sive non est de se hoc. Quaes. Super, L. VII, Q.13, 61. ${ }^{79}$ nulla unitas realis naturae est minor haecitate, nec unitas realis supposit est minor. Quaes. Super, L. VII, Q.13, 61.
}

${ }^{80}$ A heceidade tem sido tratada como o traço mais original de Scotus (MATTOS, Carlos Lopes de. Duns Scot/Ockham. Vida e Obra. Introdução do Volume Duns Scot/Ockham da série Os Pensadores. São Paulo: Nova Cultural, 1989. P. VIII) (NASCIMENTO, Carlos A. R. do."A querela dos universais revisitada". In: Cadernos PUC-Filosofia. São Paulo: Cortez, n. 13, p. 37, 1983, p. 37). Porém não é um termo muito encontrado nos textos do Doutor Sutil. A palavra latina haecceitas na concepção de Duns Scotus está intimamente ligada às concepções de essência e significa a sua individualidade última com a essência. Assim a palavra heceidade em Scotus é a "determinação individuante da essência" segundo a interpretação de Étienne Gilson (GILSON, Étienne. A filosofia na Idade Média. $2^{\underline{a}}$ edição. São Paulo: Martins Fontes, 2007, p. 746). Contudo, vemos que a heceidade é somente um vetor diante de uma concepção maior. Este conceito não varia muito em relação aos seus antecessores. Duns Scotus, ao longo da Quaestiones Super Libros Metaphysicorum Aristotelis e da Ordinatio II, dist. 3, pars 1, q. 1-7 como tema principal "De Princípio Individuationis" e a Lectura, Distinctio Tertia, Pars Prima: De principio individuationis existem poucas referências à idéia de haecceitas como o principal traço da inovação escotista. Além disso, a palavra heceidade tem menor peso do que ultima realitas, unitas realis, própria 'quod quid est', entitas etc. Entendemos, por sua vez, que a idéia de "realidade menor do que a unidade numérica" e a idéia de individualidade além das espécies (ultra speciem) seja o mais importante em Scotus do que a heceidade por ser mais explanado e aquilo que Duns Scotus dedica com mais profundidade. Um texto que dá uma boa dimensão sobre o que colocamos é de FILHO, Juvenal Savian. A metafísica de Boécio e a noção de haecceitas em Duns Escoto. Revista Signum, 2010, Volume 11, n², p. 1-19. A essência individual que Scotus desenvolve culmina na heceidade assim como ultima realitas. Contudo, o fato de não concordarmos que o termo heceidade seja o principal, não indica que ele deva ser deixado de lado. Acreditamos que o termo haecceitas de Duns Scotus, não deva ser suprimido em prol de outros. Mas que possamos dar mais atenção a termos pouco citados pela historiografia da filosofia, como os descritos acima. Estes termos têm uma função importantíssima tanto pela freqüência no texto quanto pela sua função na construção filosófica que se pretende na obra. 
completamente individual não é mais ou menos do que ele mesmo. Daí a representação de "suficiência". Os suficientes não abrem caminho para nenhuma adição. Quando atingimos a máxima individualidade o Doctor Subtilis nos sugere substituir os termos: "Assim, no lugar de "próprio" se ponha "suficiente". ${ }^{81}$ Por esta razão a suficiência de algo será a sua razão singular máxima.

A diferença individual, levando em conta a essência, se dá em três níveis ${ }^{82}$ : a) se a essência está dentro do arcabouço lógico, ela será nada mais do que uma definição e nada além da "quod quid est" da espécie. Isto se dá porque o argumento lógico admite categorias como gêneros e espécies; b) a "quod quid est" como diferente entres os indivíduos além da lógica: quando se adiciona sobre aquilo (illud) forma individual, isto é, por meio da realidade material do objeto. Aqui Scotus não deixa claro se os critérios de adição são acidentais ou não. Mas nos deixa a entender que a forma individual é o princípio que permite que o indivíduo se diferencie dos outros da mesma espécie; c) a opinião de Scotus contra os dois princípios anteriores: “digo que isto é 'pela substância dos outros'. E digo que a espécie não seria gênero por causa disto, porque a espécie não predica a partir de muitas diferenças, mas só em número. Porque a forma individual adicionada à natureza da espécie não faz a diferença específica, mas somente numeral. ${ }^{83}$

A natureza de determinada coisa una "per se" 84 excederá à natureza específica e se diferenciará dos números das divisões das espécies. Fato interessante é que Duns Scotus não nega que há uma divisão numeral entre as espécies, porém ela não é o critério verdadeiro para a construção da individualidade relativa à haecceitas. Com isso, a unidade menor do que a unidade numérica é a unidade real ${ }^{85}$. Quando o Doutor Sutil diz menor do que a unidade numérica ou numeral (minor quam unitas numeralis), ele intenciona quebrar com a generalidade que descende dos gêneros para as espécies. Se as espécies também podem ser divididas em vários números, naturalmente cada unidade numeral será menos geral do que as espécies.

Destarte, Scotus usa como exemplo Sócrates e Platão para entendermos a assertiva anterior. Um primeiro passo é aceitar que a diferença entre os indivíduos da mesma espécie pode existir: "assim, Sócrates e Platão se diferenciam em espécies, porque diferenciam dos outros da espécie" ${ }^{86}$. Porém entre eles há alguma comunidade que é a humanidade ou natureza dos homens. Em segundo lugar, entra a questão: através do que o 'isto' será 'isto'? Duns Scotus relata duas maneiras: a) Alguma natureza em Sócrates e Platão faz a diferenciação por meio deles próprios; b) Se aceitarmos que a

\footnotetext{
${ }^{81}$ Item, loco de "propria" ponatur "sufficiens". Quaes. Super, L. VII, Q.13, 63.

${ }^{82}$ Quaes. Super, L. VII, Q.13, 86-87.

${ }^{83}$ dico quod est hoc 'per substantiam aliquam'. Et dico quod species non esset genus propter hoc, quia non praedicatur de multis differentibus specie sed solum numero, quia forma individualis superaddita naturae especei non facit differentiam especificam sed numeralem solum. Quaes. Super, L. VII, Q.13, 87.

${ }^{84}$ Nesta questão, Quaes. Super, L. VII, Q.13, Duns Scotus usa como exemplo a pedra: “ se a natureza da pedra é a partir de si "esta" ou não" ( Utrum natrura lapidis de se sit haec vel non).

${ }^{85}$ Quaes. Super, L. VII, Q.13, 111.

${ }^{86}$ Ergo Socrates et Plato differunt specie, quia diferentiis alterius specei. Quaes. Super, L. VII, Q.13,125.
}

$$
58
$$


diferenciação relativa à "suficiência" repugna qualquer tipo de divisão. Diante disto, Scotus conclui: "Logo a natureza é individual circunscrita naquela diferença (...) da mesma maneira Sócrates é Sócrates" ${ }^{87}$. Também aplicado a qualquer indivíduo de qualquer espécie: "logo, nos mesmos serão muitas as diferenças individuais" 88.

A partir destas razões, o objeto, no exemplo Sócrates, como quer Duns Scotus, existe uma ordem natural unitiva ${ }^{89}$, isto é, um modo para se chegar ao uno suficiente (unum sufficiens). Nas ordens, o intelecto é o que abstrai em primeiro lugar, pois o que fica "como primeira impressão" 90 é a generalidade: Sócrates, a princípio, será só mais um, potencialmente último, mas tendendo mais à comunidade (humanidade) do que ele mesmo por si (Sócrates ser somente Sócrates). Contudo, a medida que conhecemos Sócrates, ele se encaminha à perfeição natural do conteúdo unitivo (ordinem naturalem perfectionum unitive contentarum) ${ }^{91}$. Com isso, o caminho rumo ao unitivo faz com que primeiro Sócrates seja animal e depois homem, posteriormente, antes homem do que 'este' homem e, por último, a clarificação do conteúdo próprio e suficiente (o unitivo) ${ }^{92}$.

O unitivo e seu conteúdo são o primeiro grau da singularidade, e também não é separado da realidade. Porém como a idéia de unitivo em direção ao singular "per $s e^{\prime \prime}$ é um constructo, Scotus considera em dois níveis nas possibilidades de identificação: "in re" e por meio do intelecto (per intellectum). Se o unitivo admite graus, é perfeitamente possível que possamos reconhecer nele variações que tendem da generalidade à singularidade. Contudo, se o conteúdo unitivo não é separado da realidade, ele não pode ser entendido só pela ação intelectual, pois o intelecto somente atinge o unitivo perfeito em determinado grau. Mas, para entendê-lo, é necessário aceitar a sua diferença individual. Em suma, o intelecto identifica a comunidade do ser, mas não o caracteriza. A definição do conteúdo unitivo só é possível, em realidade, por sua diferenciação individual ${ }^{93}$.

\footnotetext{
${ }^{87}$ Ergo natura est individua, circumscripta illa differentia (...) Item, Socrates est Socrates. Quaes. Super, L. VII, Q.13, 126 et 128.

${ }^{88}$ Erdo in eodem erunt multae differentiae individuales. Quaes. Super, L. VII, Q.13, 128.

${ }^{89} \mathrm{O}$ que é unitivo tem por capacidade unir segundo características comuns para a formação de um novo, porém ele pode fazer um novo segundo ele.

${ }^{90}$ Este é um traço avicenista de Duns Scotus: "quia ens per se est obiectum intellectus" (porque o ente por si é objeto do intelecto). Quaes. Super, L. VII, Q.14, 1. A base de Duns Scotus é formada nesta concepção de Avicena: "Nós dizemos: as idéias de 'existente', 'a coisa' e 'o necessário' são impressas na alma em uma primeira forma. Esta impressão não requer conhecer melhor para trazer algo sobre" (AVICENNA, Methaphysics. Livro 1, Capítulo 5, (1)). O ente enquanto ente na primeira apreensão do intelecto não é meramente separado segundo a opinião de Scotus e Avicena. Com isso, o Doctor Subtilis nos esclarece que o ente por si enquanto objeto do intelecto não é apenas ente enquanto universal, mas qualquer ente que possui razão de entidade. "Que, assim, é principalmente ente, porque é, sobretudo, substância." (et non tantum ens in universali, sed quodlibet ens in quantum habet rationem entis; quod ergo maxime est ens, quia maxime est substantia). Quaes. Super, L. VII, Q.14, 1.

${ }^{91}$ Quaes. Super, L. VII, Q.13, 131.

${ }^{92}$ Quaes. Super, L. VII, Q.13, 128.

${ }^{93}$ Quaes. Super, L. VII, Q.13, 131.
} 
Desta maneira, a importância do conteúdo unitivo fica definida assim:

...se a realidade já falada, a humanidade que está em Sócrates não é a humanidade que está em Platão, e, a diferença real é a partir das diferenças individuais do conteúdo unitivo, inseparáveis tanto aqui e acolá. Se, por outro lado, circunscrevemos a diferença daqui para lá, do mesmo modo não é a natureza una inteligida a máxima unidade em si, mas apenas aquela unidade menor da qual é comum. ${ }^{94}$

Neste sentido, as diferenças que estão por ser definidas nos unitivos irão o ser não por meio de características extrísecas entre os indivíduos da mesma espécie. Assim, Scotus é categórico: "as diferenças extrínsecas não fazem o uno 'per se'" 95 e, por sua vez, a existência é o que fará o indivíduo último uma realidade em si e por si. Já que a existência é implicação da "quod quid est".

Para a singularidade, a existência é mais singular do que universal ${ }^{96}$. Para tanto, entre os universais e a existência existem as intenções. As intenções de primeiro modo, são as apreensões gerais e não são abstraídas à primeira vista, são reais, mas simples e tidas como generalíssimas. As de secundo modo possuem muitas coisas a serem abstraídas nas quais se encontram as diferenças individuais ${ }^{97}$. Como conclusão, podemos atestar que as essências encontradas nas coisas singulares são abstraídas de segundo modo pela natureza na própria coisa e não de forma puramente intelectual como as características universais ou do ens in quantum ens.

Entre os singulares e as funções intelectivas, por sua vez, o limite lógico é colocado em questão oscilando entre a relação intelectual e a real. Os três níveis ficam-se assim definidos: i) Pelos extremos (Base Silogística98): Se se conhece "per se" os extremos, se conhece a diferença, isto é, a característica que um algo (aliquid) possui se faz com base na própria coisa e na extrema diferença; ii) a relação intelectual: o intelecto está entre o universal e o singular, mas conhece ambos os extremos pelo senso comum (de sensu communi) ; iii) O intelecto é o que define os nomes nas coisas e, também, atribui intenções, como esclarece Duns Scotus sobre a possibilidade de diferenciar o "singular" do "indivíduo" e também as proposições e oposições. Como estes termos estão entre a intelecção e a singularidade, o Doutor Sutil deixa claro que: "Por esta razão, certo é que a singularidade não impede a intelecção"

\footnotetext{
${ }^{94}$ si realiter loquamur, humanitas quae est in Socrate non est humanitas quae est in Platone, et realis differentia est ex differentiis individualibus unitive contentis, inseparabilibus hinc inde. Si autem circunscribamus differentiam hinc inde, sicut nec natura inlelligitur una maxima unitate in se sed tantum illa unitate minore quae est comunis. Quaes. Super, L. VII, Q.13, 144.

${ }^{95}$ Quaes. Super, L. VII, Q.13, 150.

${ }^{96}$ Quaes. Super, L. VII, Q.13, 162.

${ }^{97}$ Quaes. Super, L. VII, Q.13, 166.

${ }^{98}$ Duns Scotus está afirmando este nível a partir dos Analíticos Posteriores de Aristóteles.
} 
${ }^{99}$, porém ela não é a pré-condição para que as coisas singulares sejam o que são em sua realidade.

A operação intelectual pode atingir a questão lógica e a entidade do "ente enquanto ente". Contudo, a qüididade tem por condição sine qua non a materialidade da coisa. O plano da questão de Scotus é que se a singularidade é por si intelegida ${ }^{100}$, e com isso engloba a qüididade. Entre a materialidade da coisa e a intelecção é certo que a "quod quid est" parte da materialidade. Assim, a singularidade nesta questão foi chamada por Scotus de espécie assinalada (specie signata) que, na verdade, é um "quid". Sobre a qüididade e a função intelectiva dos singulares, temos duas vias, uma contra e outra a favor ${ }^{101}$ :

A) Contra: Como exemplo, se dois singulares "per se" inteligíveis serão dois singulares inteligíveis. Assim, os dois singulares possuirão duas qüididades e, por conseqüência, duas definições para serem duas espécies.

B) Resposta (opinião de Scotus): $O$ intelecto intelige senão a qüididade que é absoluta ou universal e as substâncias simples. Um "hoc quid", ou seja, uma coisa no estado atual assinalada ou um "o que é" não admite um inferior por ser o último nas divisões das espécies. Assim, ele conclui: "Mas o 'quid' possui um 'hoc quid' que não é ente pelos acidentes, por sua vez, é por si inteligível; contudo, estas duas 'quid' não possuem duas definições" 102.

Claramente fica expresso que as definições dos singulares não podem admitir múltiplas essências. O que podemos entender é que as opiniões acima diferem na disparidade construída entre os universais e os singulares. Estas provas são dadas como conseqüentes pelo Doctor Subtilis: se por um lado o singular é por si inteligível, logo ele não é universal, o que torna demonstrável a sua improbabilidade. Por outro lado, a conseqüência desta afirmativa traz a idéia que tanto o universal quanto o singular são por si inteligidos, mas, respectivamente, um é por intermédio de outros e a outra por si. Nesta última proposição, aparentemente existe uma incongruência: Se os universais e os singulares são inteligidos, tudo então se reduz à apreensão mental? O Doutor Sutil diria que não, mas com ressalvas. Ele explicaria assim: tudo, naturalmente passa pelo intelecto e pela razão. Porém nos universais existem somente nas coisas ligadas à comunidade e, por sua vez, são concebidas pela razão intelectual. Por outro lado, os singulares são caracterizáveis por si, as razões intelectivas estão na própria coisa material e real. Assim, como conclusão, os universais são percebidos segundo o exemplo: a humanidade. A humanidade só é conhecida porque os humanos a compartilham e, assim, ela só existe porque ela está também no outro. Caso contrário, se ela fosse por si mesmo, só existiria uma humanidade em um só homem. Em outra via, existem os singulares e indivíduos: para os identificarmos basta conhecermos eles próprios, isto é, se quisermos saber quem é Mateus, Marcos, Lucas ou João, basta visualizarmos os próprios e nada mais.

\footnotetext{
${ }^{99}$ Ergo certum est quod singularitas non impedit intellectionem. Quaes. Super, L. VII, Q.14, 7.

100 Utrum singulare per se intelligatur. Quaes. Super, L. VII, Q.14.

${ }^{101}$ Quaes. Super, L. VII, Q.14, 11 et 12.

102 Quaes. Super, L. VII, Q.14, 12.
}

\section{1}


Eles existem por si. Portanto, se eles não fossem suficientes a partir de si mesmos, naturalmente, seriam comunidades e não singularidades ${ }^{103}$.

Os princípios escotistas que evocam a singularidade, o intelecto e a essência se constroem em objeção aos princípios de Santo Tomás de Aquino ${ }^{104}$. Este é um ponto decisivo no trabalho de Duns Scotus. Com relação às condenações de 1277, que atacavam os princípios tomistas da individuação e as concepções da materialidade para a individuação, O Doctor Subtilis fez jus ao seu epíteto, isto é, reafirmou Aristóteles sem ser categórico ou abrir margem para alguma condenação. Formalmente, Duns Scotus discorda de Santo Tomás que a entidade máxima se dá pelos singulares, mas não como uma simples oposição como o Syllabus propunha. Em nenhum momento João Duns Scotus se fez apologeta dos princípios neoplatônicos de fundo agostiniano que os teólogos de Paris defendiam somente por discordar do Aquinate. Ao contrário, cada vez mais reafirma os princípios realistas "in re" da contestadíssima, ainda na virada do século XIII para o XIV, ontologia de Aristóteles expressa na Metafísica.

Em relação à essência, vemos claramente que Scotus vai contra o princípio ontológico neo-platônico de que algo pode ser e não ser ao mesmo tempo. A essência não pode ser corrompida: ela só pode ser positiva. Além disto, rompendo com o princípio de Tomás de Aquino, Duns Scotus diz:

Quando é dito além do 'singular é o ente máximo', isto é falso nos materiais, por si falando. Ou melhor, aquilo que é formalmente, é algo singular, ou matéria individual, se faz mais a partir do não-ser do que se a essência da espécie fosse por si sem tal matéria. Porque aquele é o princípio da corrupção. ${ }^{105}$

O que Scotus contesta é a idéia tomista da separação drástica entre as substâncias primárias e secundárias em relação à realidade material, à essência e à ação intelectual. O Doutor Sutil não admite que a individualidade seja uma apreensão intelectiva: "a singularidade não é a causa por si da não inteligibilidade" ${ }^{106}$. Em outro momento ele nega que algo seja adicionado ou que a singularidade seja impedimento para a inteligibilidade. Assim, é possível inteligir, porém não é a razão por si.

A partir destas razões, Duns Scotus entende que o meio mais claro para que a "quod quid est" seja identificável é ponderar sobre a razão material dos singulares. Assim, há uma oposição clara entre a razão intelectual ligada à generalidade dos

\footnotetext{
${ }_{103}$ Quaes. Super, L. VII, Q.14, 13.

${ }^{104} \mathrm{O}$ título do argumento é: Contra responsiones datas ad mentem Thomae. Quaes. Super, L. VII, Q.14, 26.

105 Quando dicitur ultra quod 'singulare est maxime ens', hoc falsum est in materialibus, per se loquendo. Immo illud quo formaliter est aliquid singulare, ut materia individualis magis facit ad nonesse quam si essntia specei per se esset nine tali materia quia illa est principium corruptionis. Quaes. Super, L. VII, Q.14, 19.

106 Singularitas non est per se causa non intelligibilitatis. Quaes. Super, L. VII, Q.14, 26.
} 
entes e a sua singularidade que é "in re". Se a singularidade está para a essência, logo a essência é uma apreensão real, nas coisas e identificáveis "per se". Neste sentido, Scotus abre caminho para uma essência além dos numerais da divisão das espécies. O número é um último "quid" em potencial, mas não um "quid" real e material. Por outro lado, se investigarmos além da realidade numérica, será possível entendermos as razões do "quid" suficiente: identificaremos a sua "quod quid est" e a verdadeira haecceitas. A qüididade do último indivíduo suficiente é útil somente a ele: não se admite mais divisões.

\section{Conclusão.}

Desta feita, João Duns Scotus definiu a essência em princípios novos e "singularizou" a essência dos seres. A essência como algo indefinido legado a somente uma possibilidade dos números advindos da divisão das espécies agora é nomeada no indivíduo último. O seu viés realista não deve ser olhado, somente, pelo fato de o Doutor Sutil acreditar que a matéria e a correspondência com a coisa em si sejam os princípios da essência. Porém, a essência na concepção escotista pode ser encontrada em qualquer ser e é de fácil identificação. A questão da realidade encontra-se em saber que o individual suficiente é demonstrável: Sócrates é por si mesmo identificável em sua "quod quid est" e não necessita de outro para se afirmar, bem como Platão, etc..

Basicamente, se conhecermos um indivíduo (último e real) naturalmente conheceremos a sua essência. Mas não um indivíduo que possamos imaginar, isto é, algo em potência. Sócrates é Sócrates e Platão é Platão. Ambos são o que são porque são indivíduos materialmente constituídos e essencialmente distintos por suas razões intrínsecas.

O conceito de essência de Duns Scotus, em suma, é voltado para os particulares. Não genericamente os particulares, mas o último. Scotus, na obra Lectura $^{107}$ com relação ao Princípio da Individuação, chama este indivíduo último de atoma ${ }^{108}$, ou seja, aquilo que é indivisível. Sem a indivisibilidade do ser unum per se jamais o conceito de essência que Scotus desenvolve poderá ser compreendido.

A compreensão do ser é antes de tudo o caminho para o conhecimento da essência. Porém devemos fazer uma diferenciação: o ser primeiro na apreensão intelectual e o ser concreto na realidade contingencial. O ser intelectivo é universal e sua essência não pode ser compreendida de fato, ainda que admitida enquanto possibilidade. Agora, o ser real é o ser singular na individualidade última sendo

\footnotetext{
107 Lectura II, dist. 3, pars 1 q. 1, 18.

108 Em latim temos duas formas de entender o átomo: primeiro, a idéia de Atomus,-i, que é um substantivo masculino que significa corpúsculo ou átomo como em português; o segundo é Atomus, Atoma e Atomum um adjetivo que significa indivisível. O segundo é o que Scot usa para dizer última possibilidade na divisão das categorias.
}

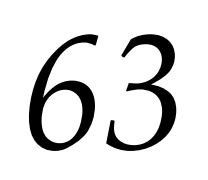


possível nele encontrar a sua essência. Édouard Jeauneau afirma que em Scotus a o ser concreto é aquele que está na singularidade como o último ${ }^{109}$.

O ser concreto em sua essência tem que ser "suficiente", pois se este ser necessita de outro, naturalmente, ele perderá a sua característica de suficiência em prol da dependência. Esta dependência pode ser acidental ou universal. Nunca a essência do ser suficiente pode trazer consigo alguma relação de adição ou comunicabilidade que rompa com sua "autonomia enquanto ser concreto". A característica de Sócrates é somente dele e unicamente partir desta suficiência ela pode ser avaliada. Assim, claramente, o Doctor Subtilis defronta com o princípio simultâneo de afirmação e negação do ser de fundo platônico-agostiniano. A essência é positiva, ou seja, só se afirma pelo que ela é. Se se pensar em "não ser" é adicionar à essência algo. Assim, será algo extrínseco e não intrínseco ou suficiente. Para ser essencialmente definível, basta somente ser último e ele mesmo.

Alain de Libera afirma que em Scotus há um processo radicalização da essência, isto é, a indiferença (fundo avicenista), pois ela possui uma unidade real. Talvez o traço original: ela não é só numérica e nem só pensada ${ }^{110}$. Assim, a natureza é também tratada como algo essencial e pode ser olhada per se e por meio da ação intelectiva. Com isto, é realidade é definida pela função da qüididade:

E é em função da qüididade assim interpretada que as proposições por si do primeiro modo são verdadeiras. Por tudo aquilo que é predicado da qüididade de uma coisa segundo o primeiro modo da predicação por si está compreendido nela essencialmente, na própria medida em que essa qüididade é separada dos indivíduos que lhes são naturalmente posteriores. ${ }^{111}$

Nós, porém, não aceitamos da idéia de "radicalização" da essência. O fato de Scotus atribuir aos individuais a essência real, não indica que ele contrastou profundamente com seus antecessores. Anteriormente à Duns Scotus, entre os medievais, a essência ficava relegada a uma definição não muito clara. Isto é, em Santo Tomás de Aquino a essência fica submetida às formas e a possibilidade dos números das espécies, mas não a definiu como última ${ }^{112}$. Os lógicos do século XII delegaram às espécies alguma característica essencial. Por outro lado, Scotus procurou definir, antes de tudo, que ciência deveria investigar a quod quid est o que ficou ao encargo da metafísica. Assim, o Doutor Sutil clarificou os limites dos universais e dos particulares, dos gêneros e das espécies e dos reais e das funções intelectivas antes de se lançar sobre a essência.

\footnotetext{
109 JEAUNEAU, Édouard. La philosophie Médiévale. ‘Que sais-je ?' Le point des connaissances actuales $\mathrm{n}{ }^{\circ}$ 1044. Paris : Presses Universitaires de France, 1963. p.108.

${ }^{110}$ DE LIBERA, Alain, A Filosofia Medieval. 2a edição. São Paulo: Edições Loyola, 2006. p. 420.

111 Idem, p. 421.

${ }_{112}$ De ente et essentia, Caput III, 24-26.
} 
Com isso, a interpretação da "radicalização da essência" empobrece todo o esforço explicativo desenvolvido por Scotus. Se fosse possível pensar em uma "radicalização", poderíamos conjecturar em uma não-consideração, por parte da filosofia escotista, das opiniões anteriores a Scotus. Assim, temos que levar em conta o próprio método escolástico que valoriza a opinião própria fundamentada nas autoridades. O Doctor Subtilis desenvolveu, sem dúvida, uma opinião inovadora quanto à "quod quid est", mas não radical. Podemos crer que a "singularização" da essência seja um esforço em dar sentido real e palpável à qüididade dos seres, mas não de forma absoluta.

Podemos, na realidade, substituir a idéia de radicalização pela de "suficiência da essência" nos seres concretos, indivisíveis e de realidade última (ultima realitas). Duns Scotus deu concretude e definição clara do que é a essência e sua função nos seres últimos e indivisíveis. Caracterizada por Gilson assim: "O ser é singular pela simples razão que como ele é a sua substância e não pode sofrer divisões" em outro momento: "há a repugnância formal de o indivíduo ser dividido em outros indivíduos" ${ }^{113}$.

Assim, Scotus nega a ação acidental para a essência, a geral e a possibilidade do número advindo da divisão das espécies. Existe algo além da indefinição dos números: é a essência dada, localizada e definível.

${ }^{113}$ GILSON, Étienne. Jean Duns Scot... op. cit., p. 452. 